\title{
Atomic-Scale Structure and Catalysis on Positively Charged Bimetallic Sites for Generation of $\mathbf{H}_{2}$
}

\author{
Yu Tang, ${ }^{\mathrm{a} \zeta}$ Shiran Zhang, ${ }^{\mathrm{a} \zeta}$ Takat B. Rawal, ${ }^{\mathrm{b} \zeta}$ Luan Nguyen, ${ }^{\mathrm{a} \zeta}$ Yasuhiro Iwasawa, ${ }^{\mathrm{c}}$

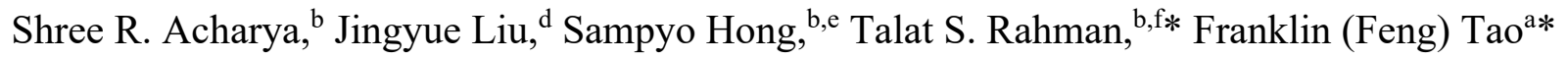

${ }^{a}$ Department of Chemical and Petroleum Engineering, University of Kansas, Lawrence, KS 66045, USA

${ }^{\mathrm{b}}$ Department of Physics, University of Central Florida, Orlando, FL 32816, USA

${ }^{c}$ The University of Electro-Communications, Chofu, Tokyo 182-8585, Japan

${ }^{\mathrm{d}}$ Department of Physics, Arizona State University, Tempe, AZ 85287, USA

'Division of Physical Sciences, Brewton-Parker College, Mount Vernon, GA 30445, USA

${ }^{\mathrm{f}}$ Renewable Energy and Chemical Transformation (REACT) Cluster, University of Central Florida, Orlando, FL 32816, USA

$\zeta$ These authors made equal contribution.

* To whom all correspondence should be addressed. Email: franklin.tao.2017@gmail.com (FT) and Talat.Rahman@ucf.edu (TR) 


\section{Experimental and computational methods}

Catalyst preparation $\left(\mathbf{P d}_{1} \mathbf{Z n}_{3} / \mathbf{Z n O}\right.$ and $\left.\mathbf{P d}-\mathbf{Z n} / \mathbf{Z n O}\right)$. Two types of catalysts, $\mathrm{Pd}_{1} \mathrm{Zn}_{3} / \mathrm{ZnO}$ consisting of isolated $\mathrm{Pd}_{1} \mathrm{Zn}_{3}$ bimetallic sites and their support $\mathrm{ZnO}$, and $\mathrm{Pd}-\mathrm{Zn} / \mathrm{ZnO}$ consisting of $\mathrm{Pd}$ $\mathrm{Zn}$ alloy nanoparticles supported on $\mathrm{ZnO}$ were synthesized. In the main text and this supplementary information, $\mathrm{Pd}-\mathrm{Zn} / \mathrm{ZnO}$ denotes Pd-Zn alloy nanoparticle.

$\mathrm{Pd}-\mathrm{Zn} / \mathrm{ZnO}$ consisting of $\mathrm{Pd}-\mathrm{Zn}$ alloy nanoparticles and the support $\mathrm{ZnO}$ is termed $5.0 \mathrm{wt} \%$ $\mathrm{Pd} / \mathrm{ZnO}-\mathrm{N}_{2}-\mathrm{H}_{2}$ catalyst. It was synthesized through a modified incipient wetness impregnation method. After impregnation, evaporation and drying at $80{ }^{\circ} \mathrm{C}$ in vacuum oven for $6 \mathrm{hrs}$ with followed calcinations at $250{ }^{\circ} \mathrm{C}$ in $\mathrm{N}_{2}$ and at $400{ }^{\circ} \mathrm{C}$ in $5 \% \mathrm{H}_{2}$ were performed for the formation of Pd-Zn alloy nanoparticles supported on $\mathrm{ZnO}$. In some cases, $\mathrm{Pd}-\mathrm{Zn} / \mathrm{ZnO}$ will also be used in the text to denote the Pd-Zn alloy nanoparticles supported on $\mathrm{ZnO}$.

$\mathrm{Pd}_{1} \mathrm{Zn}_{3} / \mathrm{ZnO}$ was synthesized via a modified deposition precipitation method by anchoring the Pd cations of $\mathrm{Pd}\left(\mathrm{NO}_{3}\right)_{2}$ on commercial $\mathrm{ZnO}$ (Alfa, $>99 \%$, nanoparticles with sizes of 20-30 nm). Preparation of catalyst precursors is prerequisite for synthesis of catalysts $(0.01 \mathrm{wt} \% \mathrm{Pd} / \mathrm{ZnO}$ and $0.05 \mathrm{wt} \% \mathrm{Pd} / \mathrm{ZnO}$ ) with isolated $\mathrm{Pd}_{1} \mathrm{Zn}_{3}$ bimetallic sites, which was done through the following steps. A suspension was obtained by mixing $\mathrm{ZnO}$ with $50 \mathrm{~mL}$ deionized water under vigorous stirring. Then, certain amount of $\mathrm{Pd}\left(\mathrm{NO}_{3}\right)_{2}$ solution was added through a controlled injection with a syringe pump when the $\mathrm{ZnO}$ suspension was being vigorously stirred. Then, $\mathrm{pH}$ of the suspension was adjusted carefully to 9.5 by gradually adding ammonium hydroxide solution, followed by continuously vigorous stirring overnight. Then, the solution was centrifuged and washed with deionized water several times, offering a precursor for preparation of catalyst, $0.01 \mathrm{wt} \% \mathrm{Pd} / \mathrm{ZnO}$ or $0.05 \mathrm{wt} \% \mathrm{Pd} / \mathrm{ZnO}$.

A well-designed pre-treatment procedure for this catalyst precursor was conducted to ensure formation of isolated bimetallic sites $\mathrm{Pd}_{1} \mathrm{Zn}_{3}$ on $\mathrm{ZnO}$. Figure $\mathrm{S} 1$ schematically illustrates evolution of 
the catalyst precursors formed in each pre-treatment step. First, the prepared precursor was dried at $60{ }^{\circ} \mathrm{C}$, binding $\mathrm{Pd}^{2+}$ to hydroxyl groups of $\mathrm{ZnO}$ surface (Figure $\mathrm{S} 1 \mathrm{~b}$ ). It was followed by calcination at $250{ }^{\circ} \mathrm{C}$ in $5 \% \mathrm{O}_{2}$ made $\mathrm{Pd}^{2+}$ cations anchored on $\mathrm{ZnO}$ surface through formation of $\mathrm{Pd}-\mathrm{O}-\mathrm{Zn}$ bonds (Figure S1c). In other words, surface species $\mathrm{Pd}_{1}-\mathrm{O}_{\mathrm{x}}-\mathrm{Zn}_{\mathrm{y}}$ was formed. Then, reduction in $5 \% \mathrm{H}_{2}$ at an appropriate temperature removed some of these $\mathrm{O}$ atoms between $\mathrm{Pd}_{1}$ and $\mathrm{Zn}_{\mathrm{y}}$ in surface species $\mathrm{Pd}_{1-}$ $\mathrm{O}_{\mathrm{x}}-\mathrm{Zn}_{\mathrm{y}}$, making each $\mathrm{Pd}_{1}$ atom directly bond to $\mathrm{Zn}$ besides $\mathrm{O}$ atoms (Figure $\mathrm{S} 1 \mathrm{~d}$ ) instead of completely binding of $\mathrm{Pd}_{1}$ to $\mathrm{O}$ atoms of $\mathrm{ZnO}$ surface (Figure $\mathrm{S} 1 \mathrm{c}$ ). In this letter, notations, $x$ wt $\%$ $\mathrm{Pd} / \mathrm{ZnO}-\mathrm{O}_{2}, x \mathrm{wt} \% \mathrm{Pd} / \mathrm{ZnO}-\mathrm{O}_{2}-\mathrm{H}_{2}$, or $x \mathrm{wt} \% \mathrm{Pd} / \mathrm{ZnO}-\mathrm{O}_{2}-\mathrm{H}_{2}$-catalysis denote a catalyst that has experienced pre-treatment(s) in $5 \% \mathrm{O}_{2}\left(-\mathrm{O}_{2}\right), 5 \% \mathrm{O}_{2}$ and then $5 \% \mathrm{H}_{2}\left(-\mathrm{O}_{2}-\mathrm{H}_{2}\right)$, or $5 \% \mathrm{O}_{2}$ and then $5 \%$ $\mathrm{H}_{2}$ followed with catalysis $\left(-\mathrm{O}_{2}-\mathrm{H}_{2}\right.$-catalysis), respectively. In addition, $\mathrm{Pd} / \mathrm{ZnO}$ or $x \mathrm{wt} \% \mathrm{Pd} / \mathrm{ZnO}$ is referenced to a catalyst regardless of loadings of $\mathrm{Pd}$ and/or pre-treatment procedures. Also, $\mathrm{Pd}_{1} \mathrm{Zn}_{3} / \mathrm{ZnO}$ represents the catalysts of singly dispersed bimetallic sites anchored on $\mathrm{ZnO}$ including $0.01 \mathrm{wt} \% \mathrm{Pd} / \mathrm{ZnO}$ and $0.05 \mathrm{wt} \% \mathrm{Pd} / \mathrm{ZnO}$.

Structural and chemical characterizations. Structural information of catalyst nanoparticles was studied with TEM. ${ }^{1}$ High-Angle Annular Dark-Field Scanning Transmission Electron Microscopy (HAADF-STEM) images were obtained on JEOL JEM-ARM 200F with a CEOS probe corrector at Arizona State University (the used accelerating voltage is $80 \mathrm{kV}$ or $200 \mathrm{kV}$ and the HAADF-STEM resolution is $0.1 \mathrm{~nm}$ ).

Surfaces of catalysts were characterized with XPS and AP-XPS. Method using XPS in studying surface of a sample in gas at a relatively high pressure is termed ambient pressure X-ray photoelectron spectroscopy (AP-XPS). Effort for studying surface of a sample in gaseous environment at a relatively high pressure was made as early as 1970 's. ${ }^{2-9}$ In $1970-1980$ s', scientists demonstrated successful studies of surface of a solid or even liquid in gaseous environment at a 
relatively high pressure. ${ }^{2-5}$ AP-XPS has been a widely used surface analytical method in the community of catalysis and surface science in the last two decades. ${ }^{10}$ Here the relatively high pressure is referred to an gaseous environment with pressure higher than the pressure of vacuum environment instead of a gaseous environment with pressure higher than 1 bar. For instance, with AP-XPS scientists are able to characterize samples in gas with a pressure up to sub-Torr or a few Torr for high surface area catalysts and even up to 25 Torr for surface of single crystals. ${ }^{10,11}$ In addition, many efforts have been made in instrumentation of AP-XPS for using synchrotron or lab-based X-ray source in the last a few decades. ${ }^{8,9,11}$ Instruments of AP-XPS are available for public use at over fifteen synchrotron centres worldwide without user fee but based on peer review process of user proposals.

Complete lab-based instruments of AP-XPS for characterizing surface of a catalyst in gas phase have been available from manufacturers of Europe countries since 2010 and even earlier. Meanwhile, all parts of an AP-XPS system including different X-ray sources ( $\mathrm{Al} \mathrm{K \alpha}, \mathrm{Ag} \mathrm{L} \alpha$, soft Xray sourced, electron gun powered rotating target X-ray source), ambient or near ambient pressure energy analyser, various reaction cells working up to different pressure, UHV chamber, monochromator, metal aperture (nozzle) and its adapter between sample and energy analyser have been available from two main manufactures in Europe readily for purchasing to assemble in a lab for pursuing a cost lower than a complete system and a more convenient use for over a decade. Tao group purchased commercial system and assembled package of commercial parts from SPECS and other vendors of Europe and stainless-steel chambers and UHV parts from domestic vendors, which are among 30 lab-based AP-XPS systems made by manufacturers in Europe countries including more than fifteen lab-based AP-XPS systems in Europe, several in USA and about fifteen systems in Asia (nearly ten in China, a few in Japan, at least two in Korea, two in India, and one in Singapore). 
Assembly of commercial parts in research labs by lab staff or students can make AP-XPS be able to be used conveniently although no intellectual properties could be generated in the activity of assembly of these commercial parts because assembly of stainless-steel chambers and vacuum parts has been a routine practice in hundreds if not thousands of surface science labs in the world since 1950's. APXPS has been largely used in our studies of catalysis with a goal of fundamental understanding catalytic reaction mechanism at a molecular level. It has contributed to most of our publications in the last decade. Numerous scientists of hundreds of publications have used AP-XPS in their studies of surface science and catalysis in the last two decades. These fundamental understandings of catalytic reactions at a molecular level through AP-XPS have been summarized and reviewed recently. ${ }^{9}, 10$ Effort in pursuing AP-XPS studies at a higher pressure and pursuing high surface sensitivity has been made. Rotating target X-ray source and soft X-ray source were developed several decades ago. ${ }^{11}$ As tests to have AP-XPS using soft X-ray/rotating Al Ka anode working at pressure higher than 25 Torr and high surface sensitivity failed (Figure S2c and S2d), currently AP-XPS studies of samples of high surface area catalysts are still performed at pressure of a few Torr or sub-Torr although single crystal samples such as Ag thin film can be studied with AP-XPS at 25 Torr.

Catalyst was loaded on an Au foil (99.99\%, $0.5 \mathrm{~mm}$ thick, VWR). The operando studies of catalysts were carried out in a mixture of 1 Torr $\mathrm{CH}_{3} \mathrm{OH}$ and $0.5 \mathrm{Torr}_{2}$ (99.99\%, Praxair). Positions of signals of $\mathrm{Pd} 3 \mathrm{~d}, \mathrm{Zn} 2 \mathrm{p}$, and $\mathrm{O}$ 1s were calibrated by aligning the peak position of $\mathrm{Au} 4 \mathrm{f}_{7 / 2}$ to 84.0 $\mathrm{eV}$. While surface of a catalyst during catalysis was being examined with AP-XPS, gas composition around the catalyst surface was being simultaneously measured with a mass spectrometer in on-line mode, by which a direct correlation between surface chemistry of the catalyst during catalysis and its corresponding catalytic performance can be established. 
Operando studies using X-ray Absorption Near Edge Structure (XANES) and Extended Xray Absorption Fine Structure (EXAFS) were performed for tracking oxidation state and coordination environment of Pd atoms of catalysts at SSRL, APS and NLSL-II. The reaction cell was constructed through integration of Kapton tubes and with external heating using tungsten wire. ${ }^{12,13} 0.01 \mathrm{wt} \%$ $\mathrm{Pd} / \mathrm{ZnO}$ pre-calcinated in $5 \% \mathrm{O}_{2}$ at $250^{\circ} \mathrm{C}$ was characterized in the mixture of $\mathrm{CH}_{3} \mathrm{OH}$ and $\mathrm{O}_{2}$ at $100^{\circ} \mathrm{C}-150^{\circ} \mathrm{C}$ upon both pre-treatment (reduction in $5 \% \mathrm{H}_{2}$ at $300^{\circ} \mathrm{C}$ ) and catalysis at $290^{\circ} \mathrm{C}$. ARTEMINS and ARTHENA software were used in data processing and analyses.

Measurements of catalytic performance. Catalytic activity in conversion of methanol and selectivity for production of $\mathrm{H}_{2}$ on $0.01 \mathrm{wt} \% \mathrm{Pd} / \mathrm{ZnO}-\mathrm{O}_{2}-\mathrm{H}_{2}, 5.0 \mathrm{wt} \% \mathrm{Pd} / \mathrm{ZnO}-\mathrm{N}_{2}-\mathrm{H}_{2}$ or pure $\mathrm{ZnO}$ were measured in a fixed-bed flow reactor. Certain amount of catalyst was loaded to the reactor. $10 \mu 1 / \mathrm{min}$ liquid methanol was injected into stainless steel tube through a HPLC pump. Methanol vapor was generated by warming liquid methanol at $110^{\circ} \mathrm{C}$. Next, methanol vapor formed through vaporization at $110^{\circ} \mathrm{C}$ was mixed with $60 \mathrm{ml} / \mathrm{min} 5 \% \mathrm{O}_{2}$ (balanced with $95 \% \mathrm{Ar}$ ) and subsequently flew into the fixed-bed flow reactor. Gas components of the mixture taken from down-stream of the fixed-bed flow reactor were separated through GC columns and then measured with detector of gas chromatography in an on-line mode. Catalytic selectivity for production of $\mathrm{H}_{2}$ and $\mathrm{CO}_{2}$ were evaluated with the formulae, $S_{\mathrm{H}_{2}}=\frac{N_{\mathrm{H}_{2}}}{N_{\mathrm{H}_{2}}+N_{\mathrm{H}_{2} \mathrm{O}}}=\frac{N_{\mathrm{H}_{2}}}{2 \times N_{\text {converted methanol }}}$ and $S_{\mathrm{CO}_{2}}=\frac{N_{\mathrm{CO}_{2}}}{N_{\mathrm{CO}_{2}}+N_{\mathrm{CO}}}$, where $\mathrm{N}$ is the amount of gas (in mol) generated or consumed per second. Blank experiments using $\mathrm{ZnO}$ were done in the temperature range of $210-350^{\circ} \mathrm{C}$ to check the contribution of $\mathrm{ZnO}$ to $\mathrm{MPO}$.

Method of computational studies. Rahman Group at UCF performed first-principles calculations with the VASP code. The PBE exchange-correlation functional was used for the electronelectron interaction. The ion-interaction was described by the pseudopotential generated with the projector-augmented wave (PAW) ${ }^{14-15}$ method. The kinetic energy cutoff of $400 \mathrm{eV}$ was used for plane 
waves. All atoms of the systems were relaxed until the total energy was converged to $10^{-5} \mathrm{eV}$ and the force on each atom was reduced below $0.01 \mathrm{eV} / \AA$. For $\mathrm{Pd}_{1} \mathrm{Zn}_{3} / \mathrm{ZnO}$, the $(4 \times 3 \times 1) \mathrm{k}$-point mesh with irreducible k-point generation according to the Monkhorst-Pack scheme ${ }^{16}$ was used, and for the Pd$\mathrm{Zn}$ alloy nanoparticle (simulated as $\mathrm{Pd}_{16} \mathrm{Zn}_{16}$ alloy nanoparticle here) only one k-point was employed.

For pure $\mathrm{ZnO}(10 \overline{1} 0)$ supercell of the $(4 \times 4)$ unit cell and $16 \AA$ vacuum was constructed using our calculated lattice constants of $\mathrm{a}=3.282 \AA$ and $\mathrm{c}=5.308 \AA$, which are in good agreement with experimental values $(\mathrm{a}=3.250 \AA$ and $\mathrm{c}=5.206 \AA)$ reported in literature. ${ }^{17}$ To model a singly-dispersed $\mathrm{Pd}$ atom on $\mathrm{ZnO}(10 \overline{1} 0)$, i.e. $\mathrm{Pd}_{1} \mathrm{Zn}_{3} / \mathrm{ZnO}$, an $\mathrm{O}$ atom of $\mathrm{ZnO}$ surface was substituted by a $\mathrm{Pd}$ atom since our calculated formation energy of the $\mathrm{Zn}$ vacancy $(4.38 \mathrm{eV})$ is greater than that of the $\mathrm{O}$ vacancy $(3.23 \mathrm{eV})$. Our calculated $\mathrm{Pd}-\mathrm{Zn}$ distance for singly-distributed $\mathrm{Pd}$ atom on $\mathrm{ZnO}$ is $2.43 \AA$, which is in good agreement with experimental value measured with EXAFS. A Pd ${ }_{16} Z_{16}$ model (16 $\mathrm{Zn}$ and $16 \mathrm{Pd}$ atoms) was constructed to represent a Pd-Zn alloy nanoparticle (with 1:1 ratio) in the form of $\mathrm{CuAu}(\mathrm{L} 10)$ type tetragonal face-centred cubic crystal structure using the lattice parameters of $\mathrm{a}=4.11 \AA$ and $\mathrm{c}=3.35 \AA$ reported in lieterature. ${ }^{18}$ This cluster has six (111) facets and is kept in a box with size of $25 \AA \times 25 \AA \times 25 \AA$.

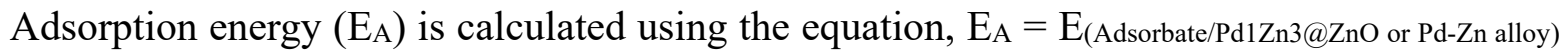

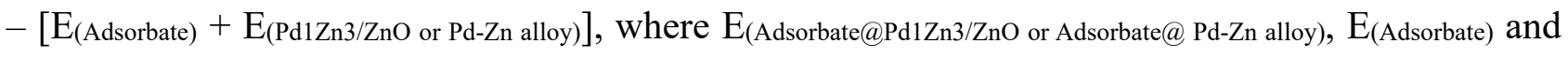
$\mathrm{E}_{(\mathrm{Pd} 1 \mathrm{Zn} 3 / \mathrm{ZnO} \text { or Pd-Zn alloy) }}$ are the total energies of $\mathrm{Pd}_{1} \mathrm{Zn}_{3} / \mathrm{ZnO}$ (or Pd-Zn alloy) with adsorbate, free adsorbate, and bare $\mathrm{Pd}_{1} \mathrm{Zn}_{3} / \mathrm{ZnO}$ [or Pd-Zn alloy], respectively. Climbing-Image NEB (CI-NEB) method was used to obtain the transition states for all promising pathways.

\section{Formation of $\mathrm{Pd}-\mathrm{Zn}$ alloy on $5.0 \mathrm{wt} \% \mathrm{Pd} / \mathrm{ZnO}$ and its catalytic performance}

For checking the difference in catalytic activity and selectivity between isolated bimetallic 
sites $\mathrm{Pd}_{1} \mathrm{Zn} 3$ and the continuously packed $\mathrm{Pd}-\mathrm{Zn}$ catalytic sites on surface of $\mathrm{Pd}-\mathrm{Zn}$ bimetallic nanoparticles, $5.0 \mathrm{wt} \% \mathrm{Pd} / \mathrm{ZnO}-\mathrm{N}_{2}-\mathrm{H}_{2}$ catalyst was prepared via incipient wetness impregnation

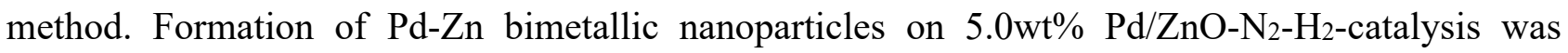
suggested by the observed diffraction peak of (111) planes of Pd-Zn alloy at $41.4^{\circ}$ (Figures S2a and $\mathrm{S} 2 \mathrm{~b})$. It was further supported by the observation of lattice fringe at $2.18 \AA$ in the high-resolution TEM image of $5.0 \mathrm{wt} \% \mathrm{Pd} / \mathrm{ZnO}-\mathrm{N}_{2}-\mathrm{H}_{2}$ (Figure $\mathrm{S} 3 \mathrm{c}$ ). This is in good agreement with the inter-planar distance of (111) face of Pd-Zn alloy nanoparticles reported in literature. ${ }^{19}$ Figure S3d plots the diffraction angles of (111) planes of pure Pd crystal, $\mathrm{Pd} 0.5 \mathrm{Zn} 0.5$ alloy with a composition of $50 \mathrm{at} \% \mathrm{Pd}$ and $50 \mathrm{at} \% \mathrm{Zn}$, and pure $\mathrm{Zn}$ crystal as a function of their corresponding compositions. The diffraction angles of (111) planes of Pd, Pd-Zn alloy and Zn (Y-axis) in Figure S3d were cited from JCPDS Card No. 46-1043, No. 06-0620, and No. 04-0831, respectively. They are plotted as a function of their corresponding concentrations of Pd atoms in Figure S3d. On this plot, diffraction angle ( $\left.41.4^{\circ}\right)$ of Pd$\mathrm{Zn}$ alloy nanoparticles of $5.0 \mathrm{wt} \% \mathrm{Pd} / \mathrm{ZnO}-\mathrm{N}_{2}-\mathrm{H}_{2}$-catalysis $\left(41.4^{\circ}\right)$ correspond to $54 \%$ of $\mathrm{Zn}$ as marked with red dash line. Thus, it is deduced that the Pd-Zn alloy nanoparticles of $5.0 \mathrm{wt} \% \mathrm{Pd} / \mathrm{ZnO}-\mathrm{N}_{2}-\mathrm{H}_{2}$ prepared in this work have a composition of $\mathrm{Pd}_{0.46} \mathrm{Zn}_{0.54}$ which is very close to that of $\operatorname{Pd} 0.5 \mathrm{Zn} 0.5$ alloy.

Catalytic performance of $5.0 \mathrm{wt} \% \mathrm{Pd} / \mathrm{ZnO}-\mathrm{N}_{2}-\mathrm{H}_{2}$-catalysis was measured under the same catalytic condition. As shown in Figure 3d, 5.0wt $\% \mathrm{Pd} / \mathrm{ZnO}-\mathrm{N}_{2}-\mathrm{H}_{2}$ exhibits quite low selectivity for production of $\mathrm{H}_{2}$ in the temperature range of $210-350^{\circ} \mathrm{C}$. It is much lower than the $91 \%$ on $0.01 \mathrm{wt} \%$ $\mathrm{Pd} / \mathrm{ZnO}-\mathrm{O}_{2}-\mathrm{H}_{2}$ at the same temperature (Figure $3 b$ ). In addition, the catalyst $\mathrm{Pd}_{1} \mathrm{Zn} 3 / \mathrm{ZnO}$ consisting of cationic $\mathrm{Pd}_{1} \mathrm{Zn}_{3}$ sites (Figure $3 b$ ) exhibits a much higher selectivity for production of $\mathrm{H}_{2}$ than $\mathrm{Pd}$ Zn alloy nanoparticle consisting of continuously packed sites (Figure 3d).

\section{Surface area and dispersion of Pd versus catalytic activity}


Surface area of $\mathrm{ZnO}$ is $42.7 \mathrm{~m}^{2} \mathrm{~g}^{-1}$. Surface area of $20 \mathrm{mg}$ of $\mathrm{Pd}-\mathrm{Zn} / \mathrm{ZnO}(5.0 \mathrm{wt} \% \mathrm{Pd} / \mathrm{ZnO}-$ $\left.\mathrm{N}_{2}-\mathrm{H}_{2}\right)$ and $20 \mathrm{mg}$ of $\mathrm{Pd}_{1} \mathrm{Zn}_{3} / \mathrm{ZnO}\left(0.01 \mathrm{wt} \% \mathrm{Pd} / \mathrm{ZnO}-\mathrm{O}_{2}-\mathrm{H}_{2}\right)$ are about $19.0 \mathrm{mg}$ and $19.9 \mathrm{mg}$, respectively. Thus, their surface areas are $0.81 \mathrm{~m}^{2}$ and $0.84 \mathrm{~m}^{2}$, respectively, which are very similar. However, their activities are distinctly different; TOFs of $\mathrm{Pd}_{1} \mathrm{Zn}_{3} / \mathrm{ZnO}\left(0.01 \mathrm{wt} \% \mathrm{Pd} / \mathrm{ZnO}-\mathrm{O}_{2}-\mathrm{H}_{2}\right)$ and $\mathrm{Pd}-\mathrm{Zn} / \mathrm{ZnO}\left(5.0 \mathrm{wt} \% \mathrm{Pd} / \mathrm{ZnO}-\mathrm{N}_{2}-\mathrm{H}_{2}\right)$ at $260^{\circ} \mathrm{C}$ are about 13.5 and $0.038 \mathrm{H}_{2}$ molecules per Pd-based site per second. Thus, surface areas of the two catalysts are irrelevant to catalytic activity in terms of turn-over frequency.

Dispersion of $\mathrm{Pd}$ on $\mathrm{Pd}_{1} \mathrm{Zn}_{3} / \mathrm{ZnO}\left(0.01 \mathrm{wt} \% \mathrm{Pd} / \mathrm{ZnO}-\mathrm{O}_{2}-\mathrm{H}_{2}\right)$ is nearly $100 \%$. The dispersion of $\mathrm{Pd}$ atoms on $\mathrm{Pd}-\mathrm{Zn} / \mathrm{ZnO}\left(5.0 \mathrm{wt} \% \mathrm{Pd} / \mathrm{ZnO}-\mathrm{N}_{2}-\mathrm{H}_{2}\right)$ is about $29 \%$. TOF of $\mathrm{Pd}_{1} \mathrm{Zn}_{3} / \mathrm{ZnO}, 13.5 \mathrm{H}_{2}$ molecules per Pd-based site per second is about 350 times of TOF of $\mathrm{Pd}-\mathrm{Zn} / \mathrm{ZnO}, 0.038 \mathrm{H}_{2}$ molecules per Pd-based site per second. As TOF is the activity normalized by the number of exposed Pd atoms on surface of the catalyst, dispersions of Pd of the two catalysts are not relevant to their activity in terms of turn-over frequency.

\section{Calculations of turn-over frequency of $5 \mathrm{wt} \% \mathrm{Pd} / \mathrm{ZnO}-\mathrm{N}_{2}-\mathrm{H}_{2}$-catalysis and $0.01 w t \% \mathrm{Pd} / \mathrm{ZnO}-\mathrm{O}_{2}-\mathrm{H}_{2}$-catalysis}

Figure S3c in the main text shows representative TEM image of the Pd-Zn alloy nanoparticles supported on $\mathrm{ZnO}$ of $5 \mathrm{wt} \% \mathrm{Pd} / \mathrm{ZnO}-\mathrm{N}_{2}-\mathrm{H}_{2}$-catalysis. Based on TEM studies, average size of $\mathrm{Pd}-\mathrm{Zn}$ alloy nanoparticles is about $2.8 \mathrm{~nm}$. To calculate the number of Pd-based active sites on the surface of Pd- $\mathrm{Zn}$ alloy of $5 \mathrm{wt} \% \mathrm{Pd} / \mathrm{ZnO}-\mathrm{N}_{2}-\mathrm{H}_{2}$-catalysis, we assumed that the shape of the $\mathrm{PdZn}$ alloy nanoparticles is cube.

Based on the correlation of diffraction angles of (111) planes of Pd, Pd0.5Zn 0.5 , and $\mathrm{Zn}$ crystals with their corresponding atomic fraction of Zn shown in Figure S3d, it is deduced that Pd-Zn alloy 
nanoparticles formed on $\mathrm{ZnO}$ of $5 \mathrm{wt} \% \mathrm{Pd} / \mathrm{ZnO}-\mathrm{O}_{2}-\mathrm{H}_{2}$-catalysis have atomic composition of $\sim 46 \%$ Pd and $\sim 54 \% \mathrm{Zn}$. With this deduced composition of Pd-Zn alloy nanocubes, we can evaluate the total number $(N)$ of Pd atoms on surface of Pd- $\mathrm{Zn}$ alloy nanocubes of $5 \mathrm{wt} \% \mathrm{Pd} / \mathrm{ZnO}-\mathrm{N}_{2}-\mathrm{H}_{2}$-catalysis.

For the convenience of evaluation of the number of Pd atoms on surface of $5 \mathrm{wt} \% \mathrm{Pd} / \mathrm{ZnO}$ participating into MPO, we assumed that $\mathrm{Pd}$ and $\mathrm{Zn}$ atoms of $\mathrm{Pd}-\mathrm{Zn}$ alloy nanocube adopted atomic packing of an FCC lattice. As Pd is the central atom of a catalytic site, we did not calculate the number of $\mathrm{Zn}$ atoms on the surface of the Pd-Zn alloy nanocube.

Here, the number $(N)$ of $\mathrm{Pd}$ atoms on the surfaces of $\mathrm{Pd}_{0.46} \mathrm{Zn}_{0.54}$ alloy nanocubes of $y$ grams of $5 \mathrm{wt} \% \mathrm{Pd} / \mathrm{ZnO}$ participating into MPO can be calculated using the equation (eq. 1) below. In this calculation, the average length $(l)$ of a nanocube is $2.8 \mathrm{~nm}$ based on TEM studies. Notably, for simplification of calculations, we made the assumption that the number of Pd atoms in a $2.8 \mathrm{~nm} \mathrm{Pd}-$ $\mathrm{Zn}$ alloy nanocube is the same as that in a $2.8 \mathrm{~nm}$ Pd nanocube. This assumption suggests that the number of Pd atoms on surface of a $2.8 \mathrm{~nm} \mathrm{Pd}-\mathrm{Zn}$ alloy nanocube is approximately close to that on the surface of a $2.8 \mathrm{~nm}$ Pd nanocube although the two numbers are different to some extent. Thus, in the following calculation, for the purpose of simplification, we calculated the number of Pd atoms on $2.8 \mathrm{~nm} \mathrm{Pd}$ nanocubes of $y$ gram of $5 \mathrm{wt} \% \mathrm{Pd} / \mathrm{ZnO}$. This number is taken as the number of $\mathrm{Pd}$ atoms on surface of $2.8 \mathrm{~nm} \mathrm{Pd} 0.46 \mathrm{Zn}_{0.54}$ nanocubes of $y$ gram of $5 \mathrm{wt} \% \mathrm{Pd} / \mathrm{ZnO}$.

$N_{\text {Pd atoms particiapting into } M P O}=\frac{\frac{5 \% \times y \text { gram } \times 6.023 \times 10^{23}}{M_{P d} \text { grams } / \text { mol }}}{N_{\text {All Pd atoms of a cube }}} \times N_{\text {Pd atom on surface of a cube }}$
In eq. $1, \frac{\frac{5 \% \times y \text { gram } \times 6.023 \times 10^{23}}{M_{P d} \text { grams } / \text { mol }}}{N_{\text {All Pd atoms of a cube }}}$ is the number of $2.8 \mathrm{~nm}$ nanocubes of $y$ gram of $5 \mathrm{wt} \% \mathrm{Pd} / \mathrm{ZnO}$ -

$\mathrm{N}_{2}-\mathrm{H}_{2} . N_{\text {All } P d}$ atoms of a cube is the number of Pd atoms of a nanocube with a size of $2.8 \mathrm{~nm}$; it can be calculated with eq. 2 :

$N_{\text {All Pd atoms of a cube }}=n_{v} \times \frac{l n m \times l n m \times l n m}{V_{P d}}$ 
The eq. 2 gives the total number of Pd atoms of a $2.8 \mathrm{~nm}$ nanocube. $V_{P d}$ is volume of a FCC lattice of Pd single crystal, $a_{P d}{ }^{3}$. Here $a_{P d}$ is the lattice constant of a Pd unit cell, $0.386 \mathrm{~nm} . n_{v}$ is the number of Pd atoms in a FCC unit cell; it is 4 for FCC of Pd single crystal.

$N_{P d \text { atom on surface of a cube }}$ in eq. 1 is the number of Pd atoms on five exposed faces of a cube with a size of $l \mathrm{~nm}$ exposed to reactants. It can be calculated with eq. 3 . $N_{P d}$ atom on surface of a cube $=n_{S} \times \frac{l n m \times l n m}{S_{P d}} \times 5$ (eq. 3). In eq. $3, l$ is length of a Pd nanocube on $\mathrm{ZnO}, 2.8 \mathrm{~nm}$. $\mathrm{n}_{\mathrm{s}}$ is the number of Pd atoms in a surface unit cell on (100) surface. For (100) surface of a FCC unit cell, it is $1 . S_{P d}$ is surface area of (100) face of a FCC unit cell, $a_{P d^{2}}$; here $a_{P d}$ is the lattice constant of a Pd unit cell, $0.386 \mathrm{~nm}$. $\mathrm{r}$ instance, with above eqs 1-3, the total number of Pd atoms of $10 \mathrm{mg}$ of $5 \mathrm{wt} \% \mathrm{Pd} / \mathrm{ZnO}-\mathrm{N}_{2}-\mathrm{H}_{2}$-catalysis and the number of $\mathrm{Pd}$ atoms on surface of the 10 $\mathrm{mg}$ of $5 \mathrm{wt} \% \mathrm{Pd} / \mathrm{ZnO}-\mathrm{N}_{2}-\mathrm{H}_{2}$-catalysis participating into MPO are $2.83 \times 10^{18}$ and $9.75 \times 10^{17}$, respectively.

On the other hand, the number of $\mathrm{Pd}$ atoms of $y$ gram of $0.01 \mathrm{wt} \% \mathrm{Pd} / \mathrm{ZnO}-\mathrm{O}_{2}-\mathrm{H}_{2}-$ catalysis can be calculated with eq.4, $N_{P d \text { atoms participating into reaction }}=\frac{0.01 \mathrm{wt} \% \times \mathrm{ygram}}{106.4 \frac{\mathrm{gram}}{\mathrm{mol}}} \times 6.023 \times 10^{23}$. For $10 \mathrm{mg}$ of $0.01 \mathrm{wt} \% \mathrm{Pd} / \mathrm{ZnO}-\mathrm{O}_{2}-\mathrm{H}_{2}$-catalysis, it is $5.68 \times 10^{15}$. Then, the number of Pd atoms of 10 $\mathrm{mg}$ of $5 \mathrm{wt} \% \mathrm{Pd} / \mathrm{ZnO}-\mathrm{N}_{2}-\mathrm{H}_{2}$-catalysis participating into MPO $\left(9.75 \times 10^{17}\right)$ is 172 times of that of 10 $\mathrm{mg}$ of $0.01 \mathrm{wt} \% \mathrm{Pd} / \mathrm{ZnO}-\mathrm{O}_{2}-\mathrm{H}_{2}$-catalysis $\left(5.68 \times 10^{15}\right)$. Furthermore, the number of Pd atoms of $\mathrm{yg}$ of $5 \mathrm{wt} \% \mathrm{Pd} / \mathrm{ZnO}-\mathrm{N}_{2}-\mathrm{H}_{2}$-catalysis participating into MPO is 172 times of that of the same weight (y $\mathrm{mg}$ ) of $0.01 \mathrm{wt} \% \mathrm{Pd} / \mathrm{ZnO}-\mathrm{O}_{2}-\mathrm{H}_{2}$-catalysis.

The number of methanol molecules introduced to the fixed-bed flow reactor of kinetics studies per second can be calculated with the following equation: 


$$
\begin{aligned}
& N_{\text {numbers of introduced methanol molecules per second }} \\
& \qquad=\frac{\text { flow rate of methanol per second } \times \text { methanol density }}{\text { methanol molar mass }} \times 6.023 \times 10^{23} \\
& =\frac{\frac{Z \mu L}{\min } \times 10^{-6} \frac{L}{\mu L} \times \frac{\mathrm{min}}{60 \mathrm{~s}} \times \frac{792 \mathrm{~g}}{L}}{32.04 \frac{\mathrm{g}}{\mathrm{mol}}} \times 6.023 \times 10^{23} \mathrm{~mol}^{-1}=2.48 \times 10^{17} \mathrm{Z}^{-1}
\end{aligned}
$$

Here, $\mathrm{z}$ is the number of $\mu \mathrm{L}$ of liquid methanol introduced to the stainless-steel tube remained at $110^{\circ} \mathrm{C}$ per second.

Next, the number of $\mathrm{H}_{2}$ molecules produced per second from a catalyst can be calculated with the following formula:

$$
N_{\text {numbers of produced } \mathrm{H} 2 \text { molecules per second }}=2.48 \times 10^{17} \times z \times 2 \times X \times S
$$

In this formula, $X$ and $S$ are conversion of methanol and selectivity for producing $\mathrm{H}_{2}$ at a temperature, respectively. Thus, TOF of either $5 \mathrm{wt} \% \mathrm{Pd} / \mathrm{ZnO}-\mathrm{N}_{2}-\mathrm{H}_{2}$ and $0.01 \mathrm{wt} \% \mathrm{Pd} / \mathrm{ZnO}$ for production of $\mathrm{H}_{2}$ through MPO at a temperature can be calculated with the equation: $T O F=$ $\frac{N_{\text {numbers of } \mathrm{H} 2 \text { produced per second }}}{N_{P \text { d atoms particiapting into } M P O}}$

\section{Computational Studies}

Chemisorption of molecular methanol. Chemisorption of reactant molecules on a catalyst surface is the first step of MPO catalytic process. ${ }^{20-21}$ Adsorptions of molecular oxygen and methanol on different sites of $\mathrm{Pt}_{1} \mathrm{Zn}_{3} / \mathrm{ZnO}$ surface were simulated. ${ }^{22}$ The energetically favourable binding configuration of $\mathrm{CH}_{3} \mathrm{OH}$ and $\mathrm{O}_{2}$ on this surface is listed in Figures $5 \mathrm{~d}$ and 5e. The adsorption energy and the optimized geometrical parameters for the adsorbed methanol and intermediates on $\mathrm{Pd}_{1} \mathrm{Zn}_{3} / \mathrm{ZnO}$ catalyst are listed in Table $\mathrm{S} 1$. 
Chemisorption of molecular oxygen. Adsorption of molecular $\mathrm{O}_{2}$ is another important step. Our DFT calculation shows that $\mathrm{O}_{2}$ does not bind at all to pure $\mathrm{ZnO}$ surface $\left(\mathrm{E}_{\mathrm{A}}=+0.29 \mathrm{eV}\right)$. However, molecular $\mathrm{O}_{2}$ strongly adsorbs on the Pd-Zn pair on the surface of the Pd-Zn alloy with adsorption energy of $-1.35 \mathrm{eV}$. Adsorption energy of $\mathrm{O}_{2}$ on the $\mathrm{Pd}-\mathrm{Zn}(\mathrm{E})$ site of $\mathrm{Pd}_{1} \mathrm{Zn}_{3} / \mathrm{ZnO}$ is $-0.83 \mathrm{eV}$. Since there can be no activation without chemisorption, molecular $\mathrm{O}_{2}$ is can be activated on the $\mathrm{Pd}-\mathrm{Zn}$ alloy surface but not on $\mathrm{ZnO}$. Notably, molecular $\mathrm{O}_{2}$ can be moderately activated by $\mathrm{Pd}_{1} \mathrm{Zn} 3 / \mathrm{ZnO}$ with a barrier of only $0.83 \mathrm{eV}$. Based on these computations, both $\mathrm{Pd}_{1} \mathrm{Zn}_{3} / \mathrm{ZnO}$ and $\mathrm{Pd}-\mathrm{Zn} / \mathrm{ZnO}$ exhibit strong adsorption for molecular methanol and molecular oxygen; thus, they are suitable for activating methanol and $\mathrm{O}_{2}$ molecules.

Dissociation of $\mathbf{O}_{2}$. In general, the stronger the adsorption of $\mathrm{O}_{2}$, the easier the breaking of the $\mathrm{O}-\mathrm{O}$ bond. ${ }^{23-25}$ The above calculations show the binding strength of molecular $\mathrm{O}_{2}$ on $\mathrm{ZnO}, \mathrm{Pd}_{1} \mathrm{Zn}_{3} / \mathrm{ZnO}$, and Pd-Zn alloy increase with the increase of coverage of Pd atom. ${ }^{22}$ Thus, strengths of binding molecular $\mathrm{O}_{2}$ to these surfaces follows the order: $\mathrm{Pd}-\mathrm{Zn} / \mathrm{ZnO}>\mathrm{Pd}_{1} \mathrm{Zn} 3 / \mathrm{ZnO}>>\mathrm{ZnO}$. In other words, $\mathrm{Pd}-\mathrm{Zn} / \mathrm{ZnO}$ is more favourable for $\mathrm{O}_{2}$ dissociation than $\mathrm{Pd}_{1} \mathrm{Zn}_{3} / \mathrm{ZnO}$. Correspondingly, our DFT calculations show that the activation barrier for dissociation of $\mathrm{O}_{2}$ on $\mathrm{Pd}-\mathrm{Zn} / \mathrm{ZnO}$ is only $0.36 \mathrm{eV}$, definitely lower than $1.10 \mathrm{eV}$, the activation barrier for dissociation of $\mathrm{O}_{2}$ on $\mathrm{Pd}_{1} \mathrm{Zn}_{3} / \mathrm{ZnO}$. In fact, dissociation of $\mathrm{O}_{2}$ is the rate-determining step of MPO on $\mathrm{Pd}_{1} \mathrm{Zn}_{3} / \mathrm{ZnO}$. As expected, the activation barrier for $\mathrm{O}_{2}$ dissociation on $\mathrm{ZnO}$ is much higher than on either $\mathrm{Pd}-\mathrm{Zn} / \mathrm{ZnO}$ and $\mathrm{Pd}_{1} \mathrm{Zn}_{3} / \mathrm{ZnO}$.

Dehydrogenation of methanol. It is known that a chemisorbed methanol molecule can preferentially dehydrogenate via $\mathrm{O}-\mathrm{H}$ bond scission to form methoxy $\left(\mathrm{CH}_{3} \mathrm{O}\right)$. Then, a stepwise $\mathrm{C}-\mathrm{H}$ bond scission of $\mathrm{CH}_{3} \mathrm{O}$ forms formaldehyde $\left(\mathrm{CH}_{2} \mathrm{O}\right)$, then formyl $(\mathrm{CHO})$ and eventually carbon monoxide $(\mathrm{CO}){ }^{26}$, ${ }^{27}$ Figure S4 presents the energetics for these elementary steps of methanol dehydrogenation on $\mathrm{Pd}_{1} \mathrm{Zn}_{3} / \mathrm{ZnO}$ and $\mathrm{Pd}-\mathrm{Zn} / \mathrm{ZnO} .^{22}$ 
The energy profiles in Figure $\mathrm{S} 4$ suggest dehydrogenation of $\mathrm{CH}_{3} \mathrm{O}$ on $\mathrm{Pd}_{1} \mathrm{Zn}_{3} / \mathrm{ZnO}$ is definitely favorable over $\mathrm{Pd}-\mathrm{Zn} / \mathrm{ZnO}$. If we assume that the highest activation barrier among these elementary steps in Figure S4 represents the overall reaction barrier, the overall barrier for dehydrogenation of $\mathrm{CH}_{3} \mathrm{OH}$ is $0.56 \mathrm{eV}$ on $\mathrm{Pd}_{1} \mathrm{Zn}_{3} / \mathrm{ZnO}, 1.33 \mathrm{eV}$ on $\mathrm{Pd}-\mathrm{Zn} / \mathrm{ZnO}$, and $2.78 \mathrm{eV}$ on pure $\mathrm{ZnO}$. From dehydrogenation of methanol point of view, the obvious difference in its activation barrier on $\mathrm{Pd}_{1} \mathrm{Zn} 3 / \mathrm{ZnO}$ and $\mathrm{Pd}-\mathrm{Zn} / \mathrm{ZnO}$ suggests that MPO is kinetically more favorable on $\mathrm{Pd}_{1} \mathrm{Zn}_{3} / \mathrm{ZnO}$ as compared to $\mathrm{Pd}-\mathrm{Zn} / \mathrm{ZnO}$. As discussed above, the activation barriers for dissociation of molecular $\mathrm{O}_{2}$ on $\mathrm{Pd}_{1} \mathrm{Zn}_{3} / \mathrm{ZnO}$ and $\mathrm{Pd}-\mathrm{Zn} / \mathrm{ZnO}$ are $1.10 \mathrm{eV}$ and $0.36 \mathrm{eV}$, respectively. The calculations in the following paragraphs suggest that formations of $\mathrm{CO}_{2}$ and $\mathrm{H}_{2}$ on $\mathrm{Pd}_{1} \mathrm{Zn}_{3} / \mathrm{ZnO}$ are kinetically favorable. Thus, if only dissociation of chemisorbed $\mathrm{O}_{2}$ and dehydrogenation of chemisorbed methanol are considered, the rate-determining steps on $\mathrm{Pd}_{1} \mathrm{Zn}_{3} / \mathrm{ZnO}$ and $\mathrm{Pd}-\mathrm{Zn} / \mathrm{ZnO}$ are dissociation of $\mathrm{O}_{2}$ and dehydrogenation of methanol, respectively.

Formation of $\mathrm{CO}_{2}$. As suggested by the above DFT calculations, pure $\mathrm{ZnO}$ is incapable of $\mathrm{O}_{2}$ adsorption and dissociation and methanol dehydrogenation. This is consistent with experimental observations. As shown in Figure $3 \mathrm{a}, \mathrm{ZnO}$ at a temperature lower than $310{ }^{\circ} \mathrm{C}$ is not active for methanol partial oxidation. Therefore, in the following paragraphs, we only discussed the difference between $\mathrm{Pd}-\mathrm{Zn} / \mathrm{ZnO}$ and $\mathrm{Pd}_{1} \mathrm{Zn} 3 / \mathrm{ZnO}$ in formation of $\mathrm{CO}_{2}$ and $\mathrm{H}_{2}$ molecules.

$\mathrm{CO}_{2}$ formation occurs through a strongly exothermic coupling between $\mathrm{CO}^{*}$ and $\mathrm{O}^{*}$. As shown with yellow line in Figure $\mathrm{S} 5$, the coupling of $\mathrm{CO}^{*}$ and $\mathrm{O}^{*}$ on $\mathrm{Pt}_{1} \mathrm{Zn}_{3} / \mathrm{ZnO}$ exhibits an activation barrier of only $0.18 \mathrm{eV} .{ }^{22}$ On the other hand, the adsorbed $\mathrm{CO}^{*}$ does not desorb at a low temperature since the desorption process on $\mathrm{Pd}_{1} \mathrm{Zn}_{3} / \mathrm{ZnO}$ needs to overcome a barrier of $1.43 \mathrm{eV}$, much higher than the activation barrier for coupling with $\mathrm{O}^{*}$ to form $\mathrm{CO}_{2(\mathrm{~g})}(0.18 \mathrm{eV})$. The ratio of activation barrier for desorption of $* \mathrm{CO}(1.43 \mathrm{eV})$ (backward step) to that of formation of $* \mathrm{CO}_{2}(0.18$ 
$\mathrm{eV}$ ) (forward step) is as high as about 8.0. This high ratio of activation barrier of backward step to forward step suggests that the forward step $\left(\mathrm{CO}_{2}\right.$ formation $)$ on $\mathrm{Pd}_{1} \mathrm{Zn} 3 / \mathrm{ZnO}$ is kinetically preferred.

Thermodynamically, formation of $\mathrm{CO}_{2} *$ through coupling $\mathrm{CO}^{*}$ and $\mathrm{O}^{*}$ on $\mathrm{Pd}-\mathrm{Zn} / \mathrm{ZnO}$ is slightly exothermic (green line in Figure S5). Kinetically, the activation barrier for forward step (coupling of $\mathrm{CO}^{*}$ and $\mathrm{O}^{*}$ ) on $\mathrm{Pd}-\mathrm{Zn} / \mathrm{ZnO}$ is $0.49 \mathrm{eV}$; the activation barrier for backward step (desorbing the adsorbed $\mathrm{CO}_{2} *$ to form free $\mathrm{CO}_{2}$ molecule) is $1.53 \mathrm{eV}$. Thus, the ratio of activation barrier of backward to forward step is only 3 , much lower than 8.0 on $\mathrm{Pd}_{1} \mathrm{Zn}_{3} / \mathrm{ZnO}$. In addition, the overall activation barrier for $\mathrm{CO}_{2}$ formation on $\mathrm{Pd}_{1} \mathrm{Zn}_{3} / \mathrm{ZnO}$ is only $0.18 \mathrm{eV}$, lower than $0.49 \mathrm{eV}$ on $\mathrm{Pd}-\mathrm{Zn} / \mathrm{ZnO}$ (Figure S5). Therefore, as compared to $\mathrm{Pd}-\mathrm{Zn} / \mathrm{ZnO}, \mathrm{Pd}_{1} \mathrm{Zn}_{3} / \mathrm{ZnO}$ is kinetically more favorable for formation of $\mathrm{CO}_{2}$.

Formation of $\mathbf{H}_{2}$. Our computational studies show that the activation barrier for coupling two adsorbed $\mathrm{H}$ atoms to form $\mathrm{H}_{2}{ }^{*}$ on $\mathrm{Pd}-\mathrm{Zn} / \mathrm{ZnO}$ is only $0.66 \mathrm{eV}$ (Figure $\mathrm{S} 6$ ). ${ }^{22}$ The reverse process of $\mathrm{H}_{2}$ formation is dissociation of molecular $\mathrm{H}_{2}$ to form atomic $\mathrm{H}$. The activation barrier of the backward step on $\mathrm{Pd}-\mathrm{Zn} / \mathrm{ZnO}$ is only $0.10 \mathrm{eV}$. Thus, the ratio of the activation barrier for dissociating $\mathrm{H}_{2}$ (backward step) to that of formation of $\mathrm{H}_{2}$ (forward step) on $\mathrm{Pd}-\mathrm{Zn} / \mathrm{ZnO}$ is $0.10 / 0.66$. This quite low ratio suggests that $\mathrm{H}_{2}$ formation on $\mathrm{Pd}-\mathrm{Zn} / \mathrm{ZnO}$ is not kinetically favorable. However, the activation barrier for forming $\mathrm{H}_{2}$ and dissociating $\mathrm{H}_{2}$ on $\mathrm{Pd}_{1} \mathrm{Zn}_{3} / \mathrm{ZnO}$ are 0.91 and $0.57 \mathrm{eV}$, respectively. The ratio on $\mathrm{Pd}_{1} \mathrm{Zn}_{3} / \mathrm{ZnO}$ is $0.91 / 0.57$. It suggests that the $\mathrm{H}_{2} *$ formation on $\mathrm{Pd}_{1} \mathrm{Zn}_{3} / \mathrm{ZnO}$ is kinetically more favorable over $\mathrm{H}_{2} *$ dissociation. Thus, a higher selectivity for $\mathrm{H}_{2}$ formation on $\mathrm{Pd}_{1} \mathrm{Zn}_{3} / \mathrm{ZnO}$ is expected to be achieved, consistent with our experimental finding that selectivity for production of $\mathrm{H}_{2}$ on $\mathrm{Pd}_{1} \mathrm{Zn}_{3} / \mathrm{ZnO}$ is obviously higher than $\mathrm{Pd}-\mathrm{Zn} / \mathrm{ZnO}$ (Figures $3 \mathrm{~b}$ and $3 \mathrm{~d}$ ). 


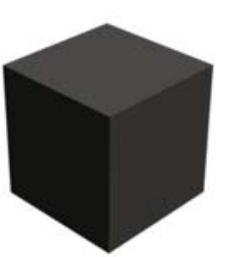

(a)

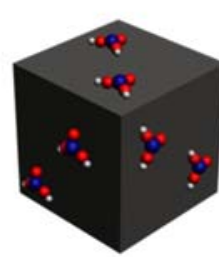

(b)

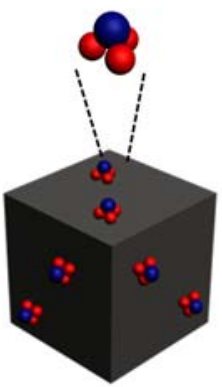

(c)

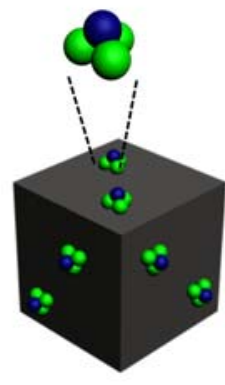

(d)

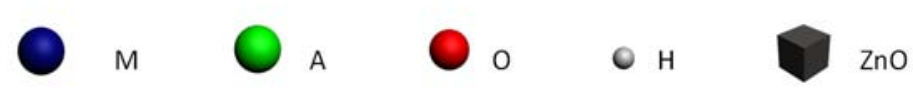

Figure S1 Schematic of preparation of a catalyst of sub-nanometer bimetallic site $\mathrm{Pd}_{1} \mathrm{Zn}_{3}$ on $\mathrm{ZnO}$. (a) Well crystallized $\mathrm{ZnO}$. (b) Deposition of Pd cations in the form of $\mathrm{Pd}_{1}(\mathrm{OH})_{z}$ species on $\mathrm{ZnO}$; the low concentration of $\mathrm{Pd}$ cations made them singly dispersed on the surface of $\mathrm{ZnO} ; \mathrm{Pd}_{1}(\mathrm{OH})_{\mathrm{z}}$ species are weakly bound to $\mathrm{ZnO}$. (c) Formation of isolated $\mathrm{Pd}_{1} \mathrm{O}_{x}$ species upon annealing in $\mathrm{O}_{2}$; $\mathrm{Pd}$ cations are bonded to $\mathrm{ZnO}$ surface through $\mathrm{Pd}_{1}-\mathrm{O}_{x}-\mathrm{Zn}_{y}$ bonds. (d) A controlled reduction in $\mathrm{H}_{2}$. 


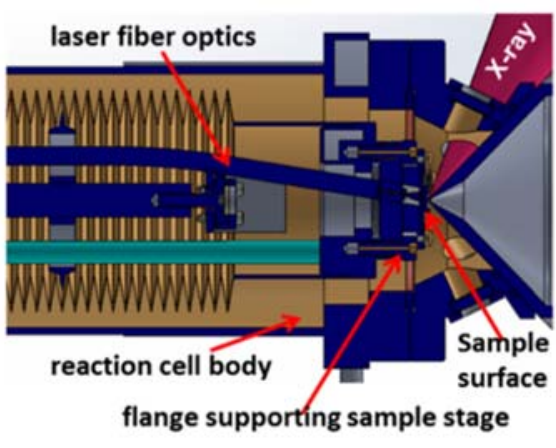

(a)

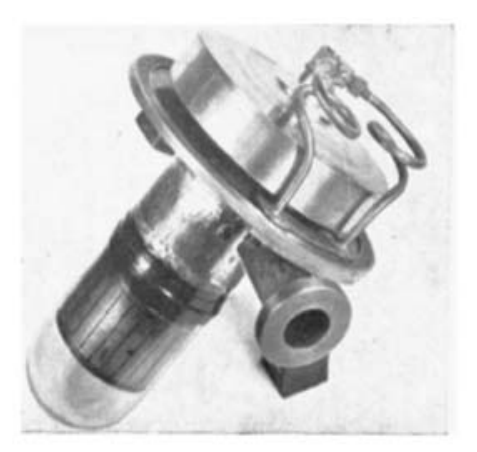

(c)

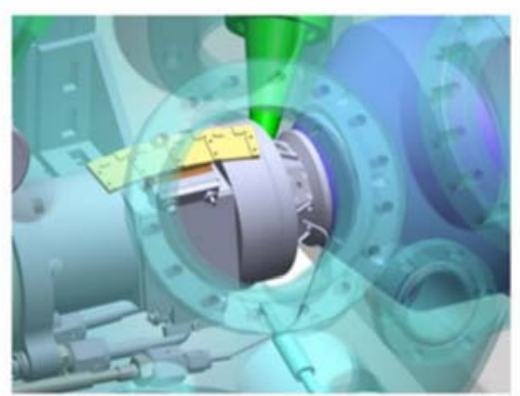

(b)

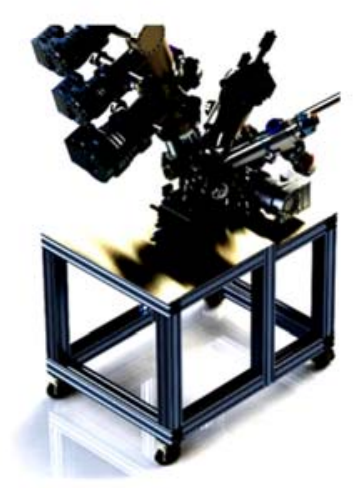

(d)

Figure S2. AP-XPS for studying catalyst surface during catalysis. (a) Reaction cell for loading a catalyst sample..$^{10}$ (b) Introduction of X-ray to a cell with reactant gas. ${ }^{10}$ (c) Schematic of soft $X$ ray/rotating target replacing $\mathrm{Al} \mathrm{K \alpha}$ anode (representative from ref 11d) used for exploring whether a sample can be studied at a pressure higher than 25 Torr; rotating target $X$-ray source was invented in several decades ago (ref 11d). (d) Schematic showing the assembly of turbo pumps, stainless steel chambers, and X-ray source and other parts. No details of the assembly were provided here as assemblies of commercial vacuum parts to a XPS or AP-XPS system can be found in numerous literature such as refs 10 and 11 and monographs. 

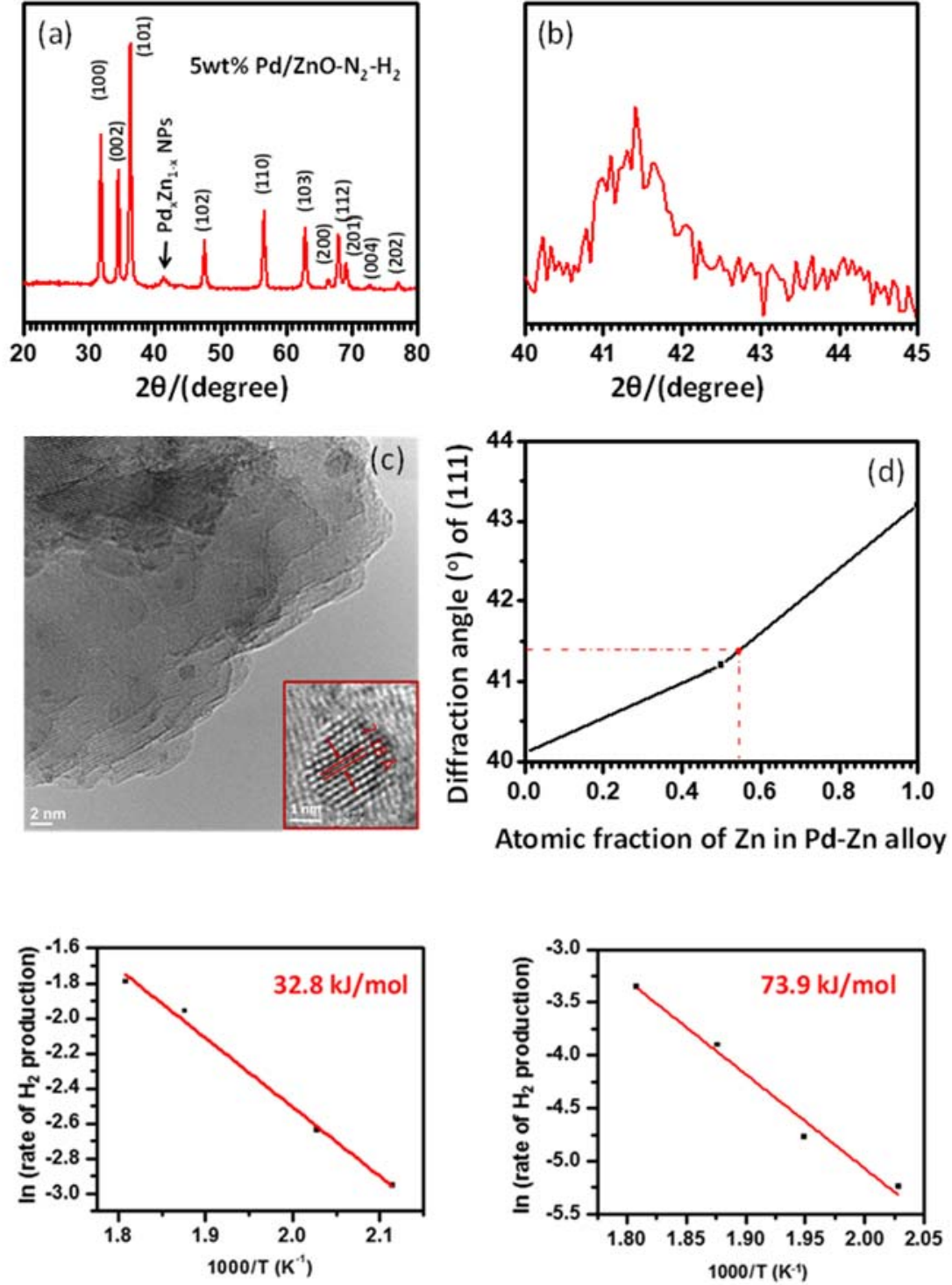

(e)

(f)

Figure S3 XRD pattern and TEM image of 5.0wt\% Pd/ZnO- $\mathrm{N}_{2}-\mathrm{H}_{2}$-catalysi and kinetics studies of $\mathrm{Pd}_{1} \mathrm{Zn} / \mathrm{ZnO}$ (singly dispersed bimetallic sites) and $\mathrm{Pd}-\mathrm{Zn} / \mathrm{ZnO}$ (bimetallic alloy nanoparticles). (a)

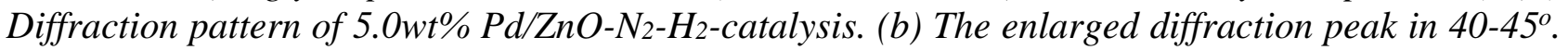
(c) HRTEM image and the lattice fringe of the alloy nanoparticles of $5.0 \mathrm{wt} \% \mathrm{Pd} / \mathrm{ZnO}-\mathrm{N}_{2}-\mathrm{H}_{2}$. (d) Correlation of diffraction angles of (111) planes of Pd crystal, Pd-Zn alloy, and Zn crystal with their corresponding compositions in terms of atomic fractions of $\mathrm{Zn}$ in these particles; the red dashed lines mark the diffraction angle $\left(41.4^{\circ}\right)$ of the Pd-Zn alloy nanoparticles formed on catalyst 5.0wt\% $\mathrm{Pd} / \mathrm{ZnO}-\mathrm{N}_{2}-\mathrm{H}_{2}$-catalysis and its composition ( $\sim 54 a t \% \mathrm{Zn}$ and $\left.\sim 46 a t \% \mathrm{Pd}\right)$. (e) Arrhenius plot of Ln (rate of producing $\mathrm{H}_{2}$ ) on $\mathrm{Pd}_{1} \mathrm{Zn}_{3} / \mathrm{ZnO}$ as a function of 1000/T; (f) Arrhenius plot of Ln (rate of producing $\mathrm{H}_{2}$ ) on $\mathrm{Pd}-\mathrm{Zn} / \mathrm{ZnO}$ as a function of 1000/T; apparent activation barrier was calculated with slope of the Arrhenius plot through the equation, $E_{a}=-8.314 \times$ slope $\mathrm{J} \mathrm{mol}^{-1}$. 


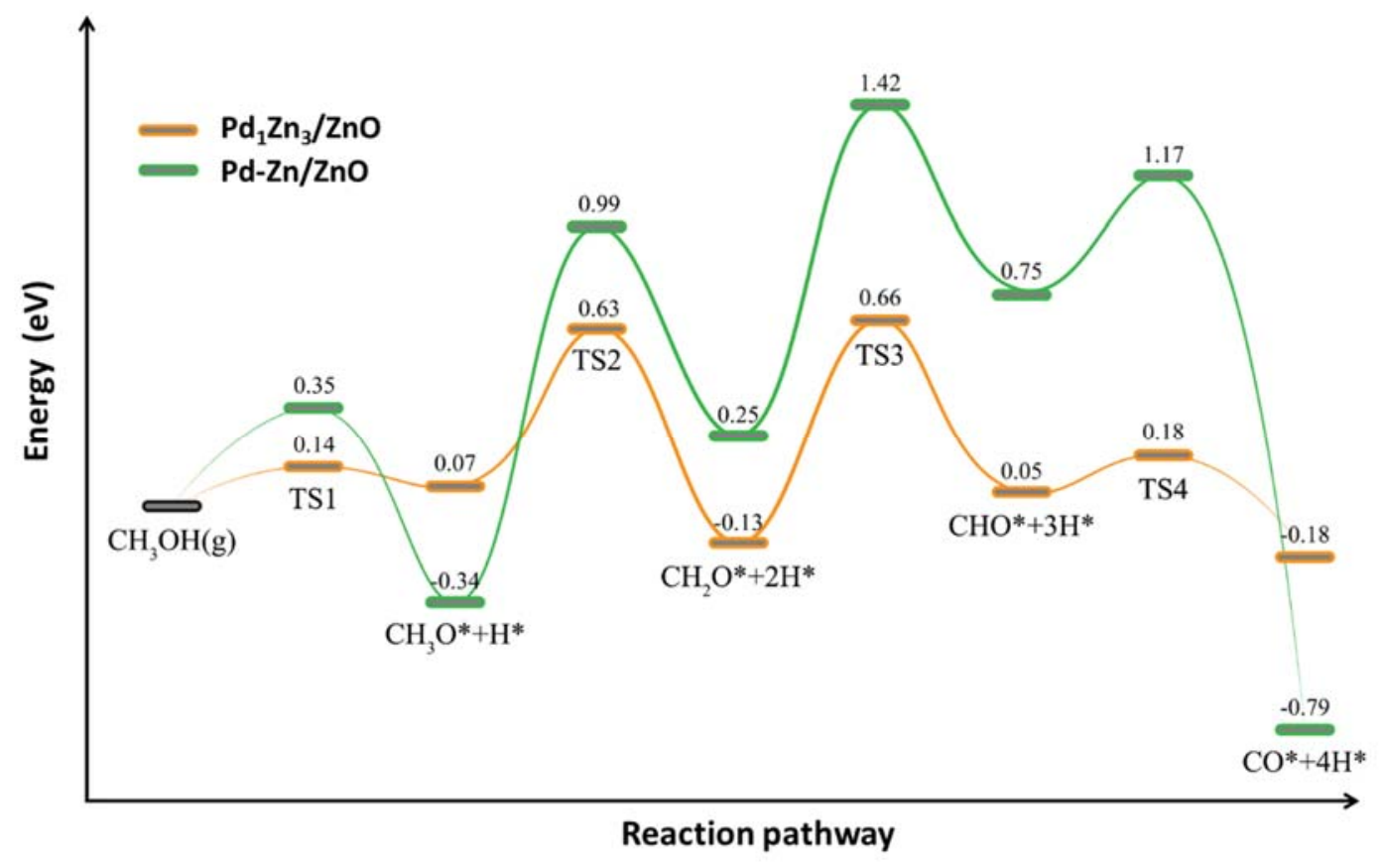

Figure S4. Represented energy profiles for dehydrogenation of methanol through dehydrogenation on $\mathrm{Pd}_{1} \mathrm{Zn}_{3} / \mathrm{ZnO}$ (yellow line) and $\mathrm{Pd}-\mathrm{Zn} / \mathrm{ZnO}$ (green line). Four transition states are marked on the energy profiles. ${ }^{22}$ 


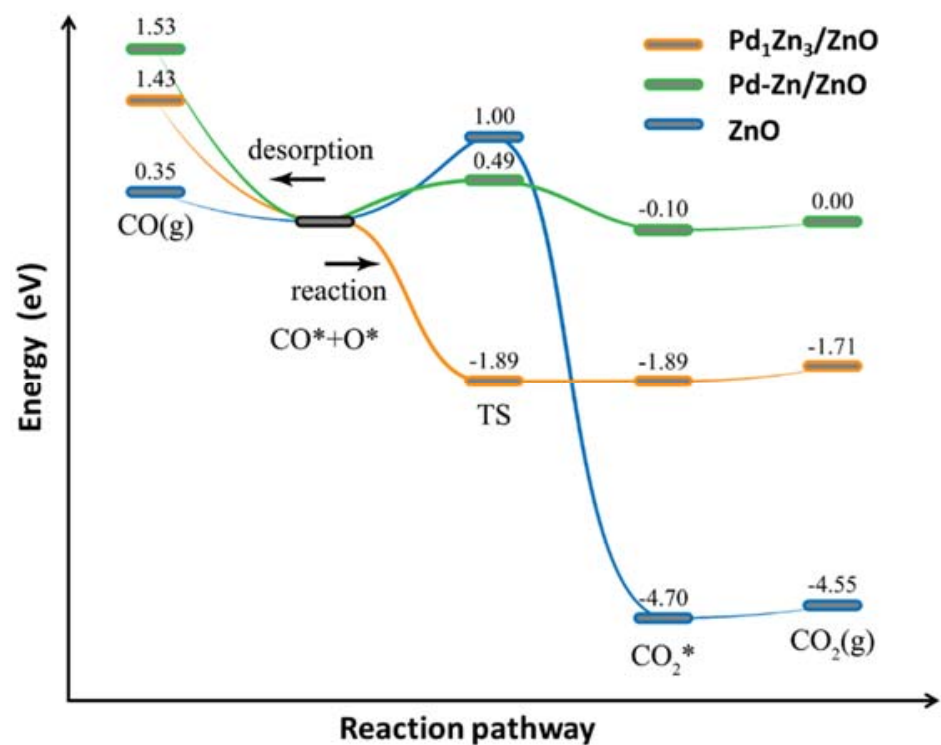

Figure S5. Represented energy profile for formation of $\mathrm{CO}_{2}$ through coupling of $\mathrm{CO}$ and $\mathrm{O}$ on $\mathrm{Pd}_{1} \mathrm{Zn} 3 / \mathrm{ZnO}$ and $\mathrm{Pd}-\mathrm{Zn} / \mathrm{ZnO}$ and pure $\mathrm{ZnO} .^{22}$ 


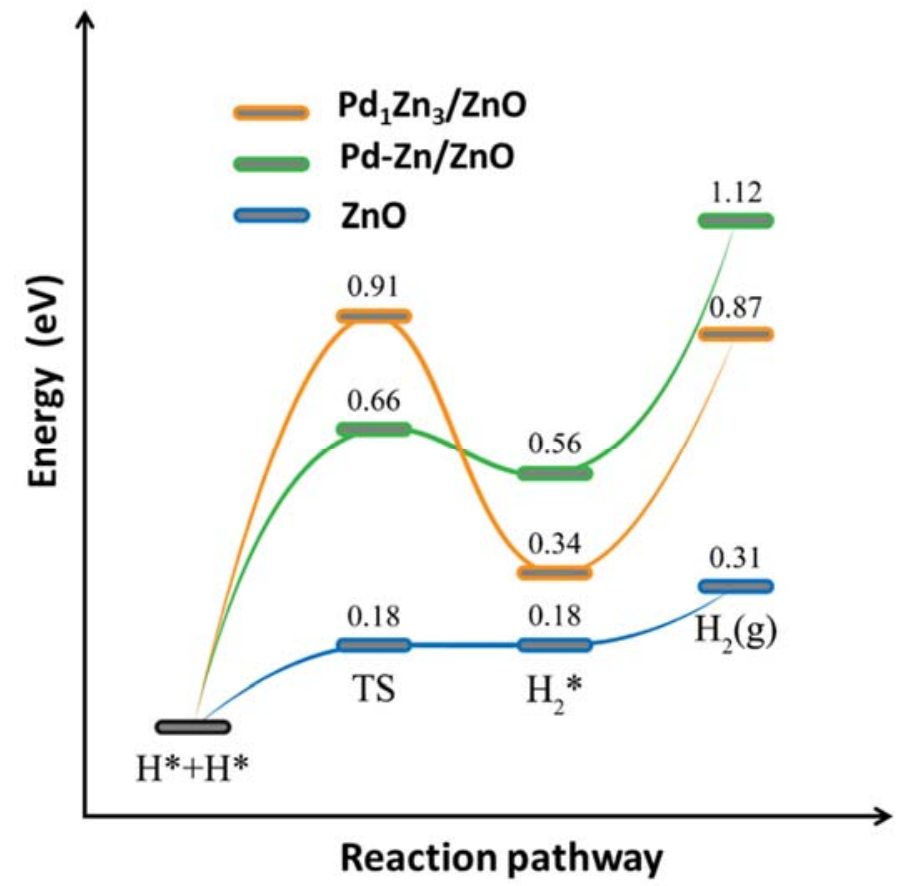

Figure S6. Represented energy profile for formation of $\mathrm{H}_{2}$ through coupling of two adsorbed $\mathrm{H}$ atoms on $\mathrm{Pd}_{1} \mathrm{Zn} n_{3} / \mathrm{ZnO}$ and $\mathrm{Pd}-\mathrm{Zn} / \mathrm{ZnO}$ and pure $\mathrm{ZnO}{ }^{22}$ 
Table S1. Adsorption energy (E) and optimized geometrical parameters for adsorbed methanol on $\mathrm{Pd}_{1} \mathrm{Zn} / \mathrm{ZnO}$ and intermediates transformed from molecularly chemisorbed methanol. The adsorption sites are labelled with letters in the parenthesis. Here, $\left(^{*}\right)$ represents a catalytic site to chemisorb a species.

\begin{tabular}{|c|c|c|c|c|c|c|c|}
\hline Adsorbates & Sites & $\mathrm{E}(\mathrm{eV})$ & $\begin{array}{c}\mathrm{O}-\mathrm{Pd} / \mathrm{O}-\mathrm{Zn} \\
(\AA)\end{array}$ & $\begin{array}{c}\text { C-Pd/C-Zn } \\
(\AA)\end{array}$ & $\begin{array}{l}\mathrm{O}-\mathrm{C} \\
(\AA)\end{array}$ & $\begin{array}{c}\mathrm{C}-\mathrm{H} / \mathrm{O}-\mathrm{H} \\
(\AA)\end{array}$ & $\begin{array}{c}\mathrm{Pd}-\mathrm{O}-\mathrm{C} \\
/ \mathrm{Zn}-\mathrm{O}-\mathrm{C} \\
\left(^{\mathrm{o}}\right)\end{array}$ \\
\hline \multirow[t]{5}{*}{$\mathrm{CH}_{3} \mathrm{OH}^{*}$} & $\mathrm{Zn}(\mathrm{D})$ & -0.42 & $3.06 / 2.16$ & $4.44 / 3.19$ & 1.45 & $1.10 / 0.98$ & $160 / 123$ \\
\hline & $\mathrm{Pd}-\mathrm{Zn}(\mathrm{D})$ & -0.63 & $2.42 / 2.41$ & $3.57 / 3.28$ & 1.46 & $1.10 / 0.98$ & $132 / 114$ \\
\hline & $\mathrm{Zn}(\mathrm{E})$ & -1.02 & $3.58 / 2.08$ & $4.71 / 3.10$ & 1.44 & $1.10 / 1.04$ & $134 / 122$ \\
\hline & $\mathrm{Zn}(\mathrm{A})$ & -0.82 & $3.72 / 2.11$ & $4.14 / 3.29$ & 1.43 & $1.10 / 1.03$ & $97 / 136$ \\
\hline & $\mathrm{Pd}$ & -0.58 & $2.27 /--$ & 3.30/-- & 1.45 & $1.10 / 0.97$ & 123/-- \\
\hline \multirow[t]{4}{*}{$\mathrm{CH}_{3} \mathrm{O}^{*}$} & $\begin{array}{l}\mathrm{Pd}-\mathrm{Zn}(\mathrm{D})- \\
\mathrm{Zn}(\mathrm{E})\end{array}$ & -2.24 & $2.34 / 2.12,2.14$ & $3.36 / 3.10,3.10$ & 1.44 & 1.10/-- & $124 / 120,118$ \\
\hline & $\mathrm{Pd}-\mathrm{Zn}(\mathrm{D})$ & -2.28 & $2.14 / 1.96$ & $3.26 / 3.04$ & 1.42 & 1.10/-- & $131 / 127$ \\
\hline & $\mathrm{Pd}-\mathrm{Zn}(\mathrm{A})$ & -2.04 & $2.15 / 1.89$ & $3.26 / 3.10$ & 1.42 & 1.10/-- & $131 / 139$ \\
\hline & $\begin{array}{c}\mathrm{Zn}(\mathrm{E})- \\
\mathrm{Zn}(\mathrm{F})\end{array}$ & -1.73 & $--/ 2.03,2.04$ & $--/ 3.09$ & 1.42 & 1.10/-- & $--/ 126$ \\
\hline \multirow[t]{4}{*}{$\mathrm{CH}_{2} \mathrm{O}^{*}$} & $\mathrm{Pd}-\mathrm{Zn}(\mathrm{D})$ & -1.00 & $2.35 / 2.08$ & $2.08 / 2.91$ & 1.30 & 1.11/-- & $--/ 116$ \\
\hline & $\begin{array}{c}\mathrm{Zn}(\mathrm{E})- \\
\mathrm{O}_{\text {surf(t) }}\end{array}$ & -0.94 & $3.95 / 1.95$ & $3.20 / 2.93$ & 1.32 & $1.11 /--$ & $--/ 126$ \\
\hline & $\mathrm{Zn}(\mathrm{E})$ & -0.50 & $--/ 2.21$ & $--/ 2.94$ & 1.32 & $1.11 /--$ & $--/ 125$ \\
\hline & $\mathrm{Zn}(\mathrm{F})$ & -0.46 & $--/ 2.20$ & $--/ 2.93$ & 1.23 & 1.11/-- & $--/ 114$ \\
\hline \multirow[t]{5}{*}{$\mathrm{CHO}^{*}$} & $\begin{array}{c}\mathrm{Zn}(\mathrm{E})- \\
\mathrm{O}_{\text {surf }(\mathrm{t})}\end{array}$ & -2.84 & $--/ 2.13$ & $2.98 / 3.03$ & 1.25 & 1.11/-- & $--/ 125$ \\
\hline & $\mathrm{Pd}$ & -1.82 & 2.87/-- & 1.98/-- & 1.21 & 1.13/-- & \\
\hline & $\mathrm{Pd}-\mathrm{O}_{\text {surf }(\mathrm{t})}$ & -2.47 & 2.27/-- & 3.03/-- & 1.24 & 1.11/-- & 117/-- \\
\hline & $\mathrm{Pd}-\mathrm{Zn}(\mathrm{E})$ & -2.00 & $3.01 / 2.20$ & $1.97 / 3.16$ & 1.23 & 1.13/-- & $--/ 132$ \\
\hline & $\mathrm{Pd}-\mathrm{Zn}(\mathrm{E})$ & -1.22 & $2.19 / 2.97$ & $3.24 / 2.07$ & 1.23 & 1.12/-- & 140/-- \\
\hline \multirow[t]{3}{*}{$\mathrm{CO}^{*}$} & $\mathrm{Pd}$ & -1.43 & & $1.94 / 4.56$ & 1.16 & & \\
\hline & $\mathrm{Zn}(\mathrm{E})$ & -0.30 & & $4.34 / 2.15$ & 1.14 & & \\
\hline & $\mathrm{Zn}(\mathrm{F})$ & -0.25 & & $--/ 2.15$ & 1.14 & & \\
\hline
\end{tabular}




\section{References}

(1) Yang, J. C.; Small, M. W.; Grieshaber, R. V.; Nuzzo, R. G., Recent developments and applications of electron microscopy to heterogeneous catalysis. Chem. Soc. Rev. 2012, 41 (24), 8179-8194.

(2) Siegbahn, K.; Nordling, C.; Johansson, G.; Hedman, J.; Heden, P. F.; Hamrin, K.; Gelius, U.; Bergmark, T.; Werme, L. O.; Manne, R.; Baer, Y. ESCA Applied to Free Molecules, Amsterdam, North-Holland,1969.

(3) Joyner, R. W.; Roberts, M. W.; Yates, K. A "high-pressure" electron spectrometer for surface studies. Surf. Sci. 1979, 87, 501-509.

(4) Siegbahn, H. Electron spectroscopy for chemical analysis of liquids and solutions. J. Phys. Chem. 1985, 89, 897-909.

(5) Littrell, D. M.; Tatarchuk, B. J. Hydrazine reduction of transition metal oxides: In situ characterization using X-ray photoelectron spectroscopy. J. Vac. Sci. Technol. 1986, 4, 1608-1612 (6) Gelius, U.; Siegbahn, K. ESCA Studies of Molecular Core and Valence Levels in the Gas Phase. Faraday Discuss. Chem. Soc. 1972, 54, 257-257. (7) Gelius, U.; Basilier, E.; Svensson, S.; Bergmark, T.; Siegbahn, K. A High Resolution ESCA Instrument with X-ray Monochromator for Gases and Solids. J. Electron Spectrosc. Relat. Phenom. 1973 , 2 ,

405-434.

(8) Ogletree, D. F.; Bluhm, H.; Lebedev, G.; Fadley, C. S.; Hussain, Z.; Salmeron, M. A Differentially Pumped Electrostatic Lens System for Photoemission Studies in the Millibar Range. Rev. Sci. Instrum. 2002, 73, 3872-3877

(9) Starr, D. E.; Liuz, Z.; Hävecker, M. ; Knop-Gericke, A.; Bluhm, H. nvestigation of solid/vapor interfaces using ambient pressure X-ray photoelectron spectroscopy, Chem. Soc. Rev. 2013, 42, 5833-5857.

(10) Nguyen, L. T., F.; Tang, Y.; Dou, J.; Bao, X. J., Understanding Catalyst Surfaces during Catalysis through Near Ambient Pressure X-ray Photoelectron Spectroscopy. Chem. Rev. 2019, 119, 6822-6905

(11) (a)Yoshimatsu, M.; Kozaki, S. Chapter: High Brilliance X-ray Sources, in Book "Topics in Applied Physics, X-ray Optics", 2005, Springer, p9-33. (b) Gelius, U.; Basilier, E.; Svensson, S.; Bergmark, T.; Siegbahn, K. A High Resolution ESCA Instrument with X-ray Monochromator for Gases and Solids, J. Electron. Spec. Related Phenomena 1974, 2, 405-434. (c) Hagstrom, S.; Siegbahn, K.; A small-angle X-ray scattering apparatus using a spherically bent crystal, $J$. Ultrastructure Res. 1960, 3, 401-419. (d) Taylor, A. On a New Type of Rotating Anode X-ray Tube, Proceed. Phys. Soc (1926-1948), 1947, 61, 86-94. (http://iopscience.iop.org/09595309/61/1/311)

(12) Nguyen, L.; Tao, F. Reactor for tracking catalyst nanoparticles in liuqid at high temperaure under a high-pressure gas phase with X-ray absorption spectrosocpy. ev. Sci. Instrument 2018, 89, 024102 .

(13) Nguyen, L.; Tang, Y.; Li, Y.; Zhang, X.; Wang, D.; Tao. F. Dual reactor for in situ/operando fluorescent mode XAS sudies of sample containing low-concentration $3 \mathrm{~d}$ and $5 \mathrm{~d}$ metal elements. Rev. Sci. Instrument 2018, 89, 054103.

(14) Blöchl, P. E., Projector augmented-wave method. Phys. Rev. B 1994, 50 (24), 17953-17979.

(15) Kresse, G.; Joubert, D., From Ultrasoft Pseudopotentials to the Projector Augmented-Wave Method. Phys. Rev. B 1999, 59, 1758-1775. 
(16) Pack, J. D.; Monkhorst, H. J., "Special points for Brillouin-zone integrations" - a reply. Phys. Rev. B 1977, 16, 1748-1749.

(17) Desgreniers, S., High-density phases of ZnO: Structural and compressive parameters. Phys. Rev. B 1998, 58, 14102-14105.

(18) Chen, Z.-X.; Neyman, K. M.; Gordienko, A. B.; Rösch, N., Surface structure and stability of PdZn and PtZn alloys: Density-functional slab model studies. Phys. Rev. B 2003, 68 (7), 075417.

(19) Castillejos-Lopez, E.; Agostini, G.; Di Michel, M.; Iglesias-Juez, A.; Bachiller-Baeza, B., Synergy of Contact between ZnO Surface Planes and PdZn Nanostructures: Morphology and Chemical Property Effects in the Intermetallic Sites for Selective 1,3-Butadiene Hydrogenation. Acs Catalysis 2017, 7, 796-811.

(20) Hendriksen, B. L. M.; Ackermann, M. D.; van Rijn, R.; Stoltz, D.; Popa, I.; Balmes, O.; Resta, A.; Wermeille, D.; Felici, R.; Ferrer, S.; Frenken, J. W. M., The role of steps in surface catalysis and reaction oscillations. Nat Chem 2010, 2, 730-734.

(21) Sievers, C.; Noda, Y.; Qi, L.; Albuquerque, E. M.; Rioux, R. M.; Scott, S. L., Phenomena Affecting Catalytic Reactions at Solid-Liquid Interfaces. Acs Catalysis 2016, 6, 8286-8307.

(22) Rawal, T. B.; Acharya, S. R.; Hong, S.; Le, D.; Tang, Y.; Tao, F.; Rahman, T. S. High Catalytic Activity of Pd1/ZnO(1010) toward Methanol Partial Oxidation: A DFT+KMC Study, ACS Catal. 2018, 8, 5563-5569.

(23) Molina, L. M.; Hammer, B., Active role of oxide support during $\mathrm{CO}$ oxidation at $\mathrm{Au} / \mathrm{MgO}$. Phys Rev Lett 2003, 90 (20).

(24) Liu, Z. P.; Gong, X. Q.; Kohanoff, J.; Sanchez, C.; Hu, P., Catalytic role of metal oxides in gold-based catalysts: A first principles study of $\mathrm{CO}$ oxidation on $\mathrm{TiO} 2$ supported Au. Phys Rev Lett 2003, 91. 266102.

(25) Rawal, T. B.; Le, D.; Rahman, T. S., Effect of Single-Layer MoS2 on the Geometry, Electronic Structure, and Reactivity of Transition Metal Nanoparticles. J Phys Chem C 2017, 121, 72827293.

(26) Desai, S. K.; Neurock, M.; Kourtakis, K., A periodic density functional theory study of the dehydrogenation of methanol over Pt(111). Journal of Physical Chemistry B 2002, 106, 25592568.

(27) Cao, D.; Lu, G. Q.; Wieckowski, A.; Wasileski, S. A.; Neurock, M., Mechanisms of methanol decomposition on platinum: A combined experimental and ab initio approach. Journal of Physical Chemistry B 2005, 109, 11622-11633. 